\title{
GAS EXCHANGE OF THE UMBU TREE UNDER SEMI-ARID CONDITIONS ${ }^{1}$
}

\author{
JOSÉ MOACIR PINHEIRO LIMA FILHO ${ }^{2}$
}

\begin{abstract}
A study was carried out at Embrapa Semi-Árido, Petrolina-PE, Brazil, aiming to understand the gas exchange process of the umbu tree (Spondias tuberosa Arr. Cam.) in the dry and rainy seasons. Stomatal conductance, transpiration, photosynthesis and internal $\mathrm{CO}_{2}$ concentration were obtained with a portable infrared gas analyzer (IRGA). During the dry season the umbu tree showed a much lower stomatal conductance early in the morning, as soon as the vapor pressure deficit increased, apparently affecting $\mathrm{CO}_{2}$ assimilation more than transpiration. The highest values were detected around 6:00 am but decreased to the lowest points between 10:00 am and 2:00 pm. During the rainy season, however, stomatal conductance, transpiration and photosynthesis were significantly higher, reaching the highest values between 8:00 and 10:00 am and the lowest around 2:00 pm. It was also observed at 4:00 pm, mainly during the rainy season, an increase on these variables indicating that the umbu tree exhibits a two-picked daily course of gas exchange.
\end{abstract}

Index terms: Spondias tuberosa, stomatal conductance, transpiration, photosynthesis, $\mathrm{CO}_{2}$ internal concentration

\section{TROCAS GASOSAS DO UMBUZEIRO SOB CONDIÇÕES SEMI-ÁRIDAS}

\begin{abstract}
RESUMO - Realizou-se um trabalho na Embrapa Semi-Árido, em Petrolina-PE, com o objetivo de estudar as trocas gasosas do umbuzeiro (Spondias tuberosa Arr. Cam.), durante as estações seca e chuvosa. Os resultados obtidos basearam-se em observações da condutância estomática, transpiração, fotossíntese e concentração interna de $\mathrm{CO}_{2}$, mensuradas com auxílio de um analisador portátil de gás infravermelho. Durante a estação seca, o umbuzeiro apresentou baixa condutividade estomática logo no início do dia, decrescendo à medida que aumentou o déficit de pressão de vapor, aparentemente afetando mais a assimilação de $\mathrm{CO}_{2}$ que a transpiração. Os valores mais altos foram observados em torno de $6 \mathrm{~h}$, decrescendo até atingir os valores mais baixos entre $10 \mathrm{~h}$ e $14 \mathrm{~h}$. Entretanto, durante a estação chuvosa, a condutividade estomática, transpiração e fotossíntese foram significativamente maiores, atingindo os valores mais altos entre $8 \mathrm{~h} \mathrm{e} 10 \mathrm{~h}$, e os mais baixos em torno das $14 \mathrm{~h}$. Constatou-se também, principalmente durante a estação chuvosa, um aumento destas variáveis às $16 \mathrm{~h}$, indicando que o umbuzeiro exibe dois picos diários de trocas gasosas.
\end{abstract}

Termos para indexação: Spondias tuberosa, condutividade estomática, transpiração, fotossíntese, concentração interna de $\mathrm{CO}_{2}$.

\section{INTRODUCTION}

The umbu tree (Spondias tuberosa Arr. Cam.) belongs to the Anacardiceae family which grows naturally in the "Caatinga" vegetation throughout the semi-arid Northeast Brazil. During the dry season, the plant shed their leaves to avoid transpiration. The flowering process begins in the dry season, when the first leaves appear at the base of the inflorescence. However, leaf flushing is enhanced after the first rains. The survival of the species in such hash environment is assured by a specialized root system bearing tubers, which function is storing water, minerals and other solutes. These resources are used during the dry season for maintaining plant normal metabolism and the beginning of the flowering process. The gathering of fruits is a very important activity for complementing the familiar income of small farmers (Mendes, 1990; Cavalcante et al., 1996).

Due to its social and economic importance, the umbu tree has been studied in relation to dispersion (Santos, 1997), propagation (Oliveira et al., 1989; Nascimento et. al, 1993), morphology (Braga, 1976), root anatomy (Lima, 1994) and fruit chemical composition (Narain et al, 1992).

Regarding its physiological behavior and interaction with the environment, very few reports are found in the literature. In this context, Ferri \& Laboriau (1952) and Ferri (1953), studied the water balance of this species during the dry season, based on stomatal behavior. They observed that maximum transpiration occurred between 7:00 am and 9:00 am.

Lima Filho \& Silva (1988), showed that the umbu tree exerts a rigid control of transpiration through the stomata, even under good soil moisture conditions, assuring a significant water economy. More recently Lima Filho (2001) studied the internal water relations of this species and suggested that under dry condition the diurnal water balance would be maintained at the expenses of water stored in the tubers and by restricted transpiration. During the rainy season, the balance may have been mediated by a short term osmotic adjustment.

In relation to gas exchange, however, nothing was found in the literature suggesting there is a need for insights on this subject. Therefore, our objective was to study the gas exchange of the umbu tree in order to understand its physiological behavior under two distinct environmental situations naturally experienced by the species.

\section{MATERIAL AND METHODS}

The experiment was carried out at the Embrapa Semi-Árido, Petrolina, Pernambuco State, Brazil, at the end of the dry season of 1994 (October) and during the rainy season of 1995 (March), after an accumulated precipitation of $510 \mathrm{~mm}$. Leaf gas exchange was monitored with a portable photosynthesis system (LI-6200 - LICOR, USA), using a $1 / 4$ liter assimilation chamber. The study was carried out on four nearby trees, grown under natural conditions and data collected on four sun exposed leaves per tree, located at the canopy midpoint. A completely randomized experimental design with four replicates was used. During the dry season, the trees had already initiated the flowering process when the first leaves appeared at the base of the inflorescence. Photosynthetic active radiation, air temperature and humidity were obtained with respective sensors connected to the LI-1000 datalogger (Licor, USA). Data on temperature and relative humidity were used to calculate the vapor pressure deficit. All data were monitored from 6:00 am to 6:00 pm during three cloudless days, on both seasons. The statistical analysis (ANOVA) was applied to compare the hourly means between seasons for each physiological variable using the SAS software.

\section{RESULTS ANDDISCUSSION}

The environmental variables recorded during physiological data measurement are presented in Figure 1. During the dry season, the photosynthetic photon flux density was higher in the morning but lower in the afternoon than during the rainy season as a result of differences in solar inclination between seasons. However, the highest value occurred at noon time, reaching around $2000 \mu \mathrm{mol} \mathrm{m}^{-2} \mathrm{~s}^{-1}$, in both seasons.

Despite the small differences in solar radiation, air temperature and vapor pressure deficit were significantly higher during the dry season. Early in the morning, temperature and vapor pressure deficit were, respectively, $25^{\circ} \mathrm{C}$ and $0.59 \mathrm{kPa}$ in the dry and $22.5^{\circ} \mathrm{C}$ and $0.36 \mathrm{kPa}$ in the rainy season. The highest values were observed around 2:00 pm, reaching

\footnotetext{
${ }^{1}$ (Trabalho 149/2003). Recebido: 09/10/2003. Aceito para publicação: 05/08/2204.

${ }^{2}$ Researcher, Embrapa Semi-Árido, Caixa Postal 23, CEP 56300-0000, Petrolina, PE, Brazil. E-mail: moacir@cpatsa-embrapa.br
} 

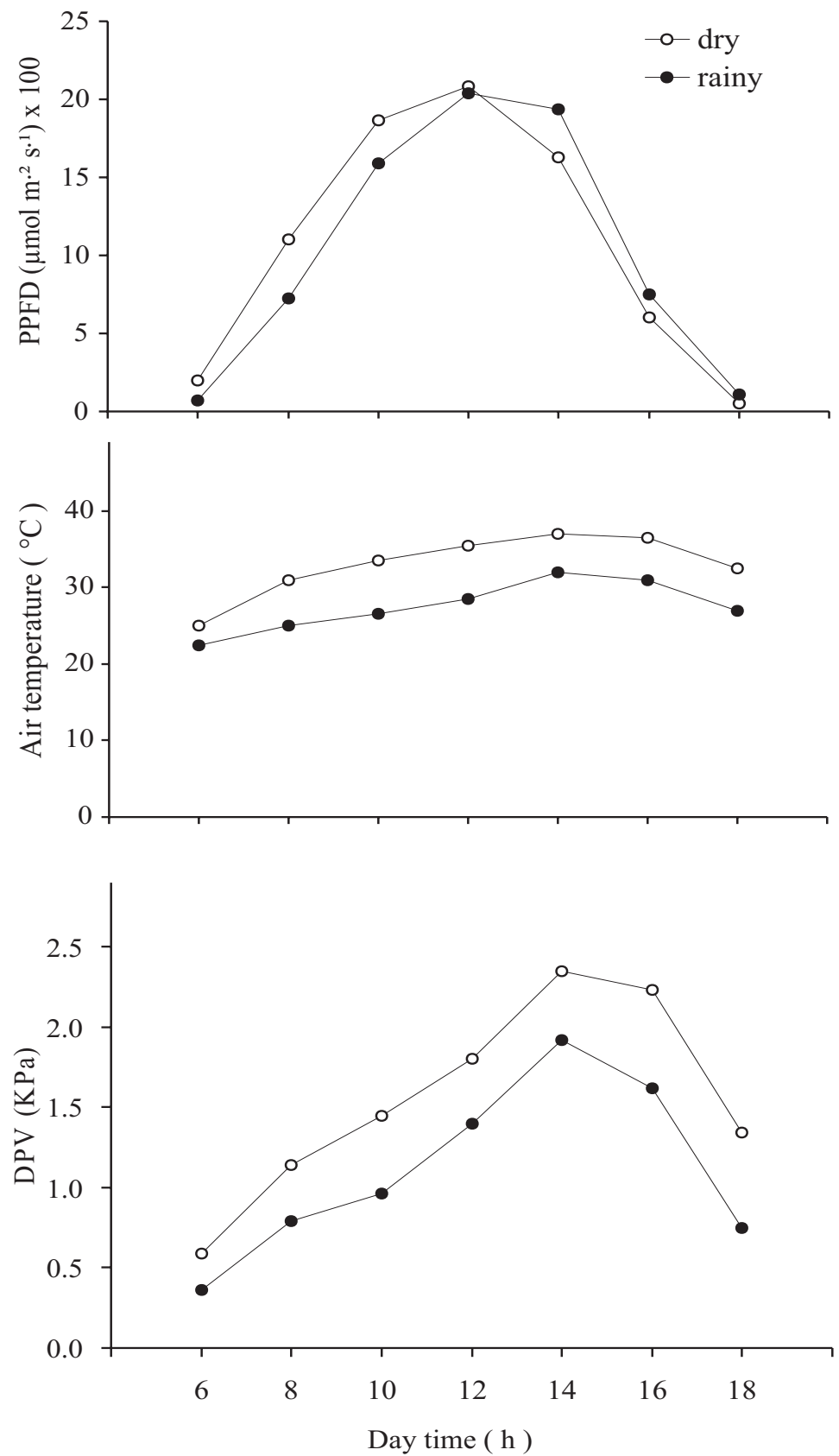

FIGURE 1- Diurnal fluctuation of photosynthetic active radiation, air temperature and vapor pressure deficit, observed in the end of the dry season of 1994 and in the rainy season of 1995.

$37{ }^{\circ} \mathrm{C}$ and $2.35 \mathrm{kPa}$ in the dry and $32^{\circ} \mathrm{C}$ and $1.92 \mathrm{kPa}$ in the rainy season.

It is evident that the differences on data observed between seasons or long term changes (Schulze \& Hall, 1982), were mostly related to the environmental differences experienced by the plants. Indeed, the statistical data analysis detected that the interaction measurement time $\mathrm{x}$ seasons was significant $(\mathrm{P}<0.01)$, indicating that the umbu tree behaved differently, within the time of measurement, regarding the distinct environmental conditions studied.

It is known that during the dry season this species maintains a favorable internal water balance at the expenses of water stored in the root tubers (Lima Filho, 2001). This adaptation should buffer the transpiration losses. However, due to the high evaporative demand, the stored water was not enough to keep the stomata wide opened. Thus, stomatal conductance, transpiration, photosynthesis but internal $\mathrm{CO}_{2}$ concentration were significantly lower and presented different hourly trend in relation to the rainy season (Figure 2).

Early in the morning, stomatal conductance was $0.16 \mathrm{~mol} \mathrm{~m}^{-2} \mathrm{~s}$ ${ }^{1}$, decreasing to $0.027 \mathrm{~mol} \mathrm{~m}^{-2} \mathrm{~s}^{-1}$ as soon as the air temperature and VPD increased from $25^{\circ} \mathrm{C}$ to $31^{\circ} \mathrm{C}$ and from $0.59 \mathrm{kPa}$ to $1.14 \mathrm{kPa}$, respectively, at 8:00 am, when radiation was below $1,000 \mu \mathrm{mol} \mathrm{m}^{-2} \mathrm{~s}^{-1}$ (Figure 1). This tendency was observed until 2:00 pm when maximum values of solar radiation, air temperature and VPD were detected. At this point,

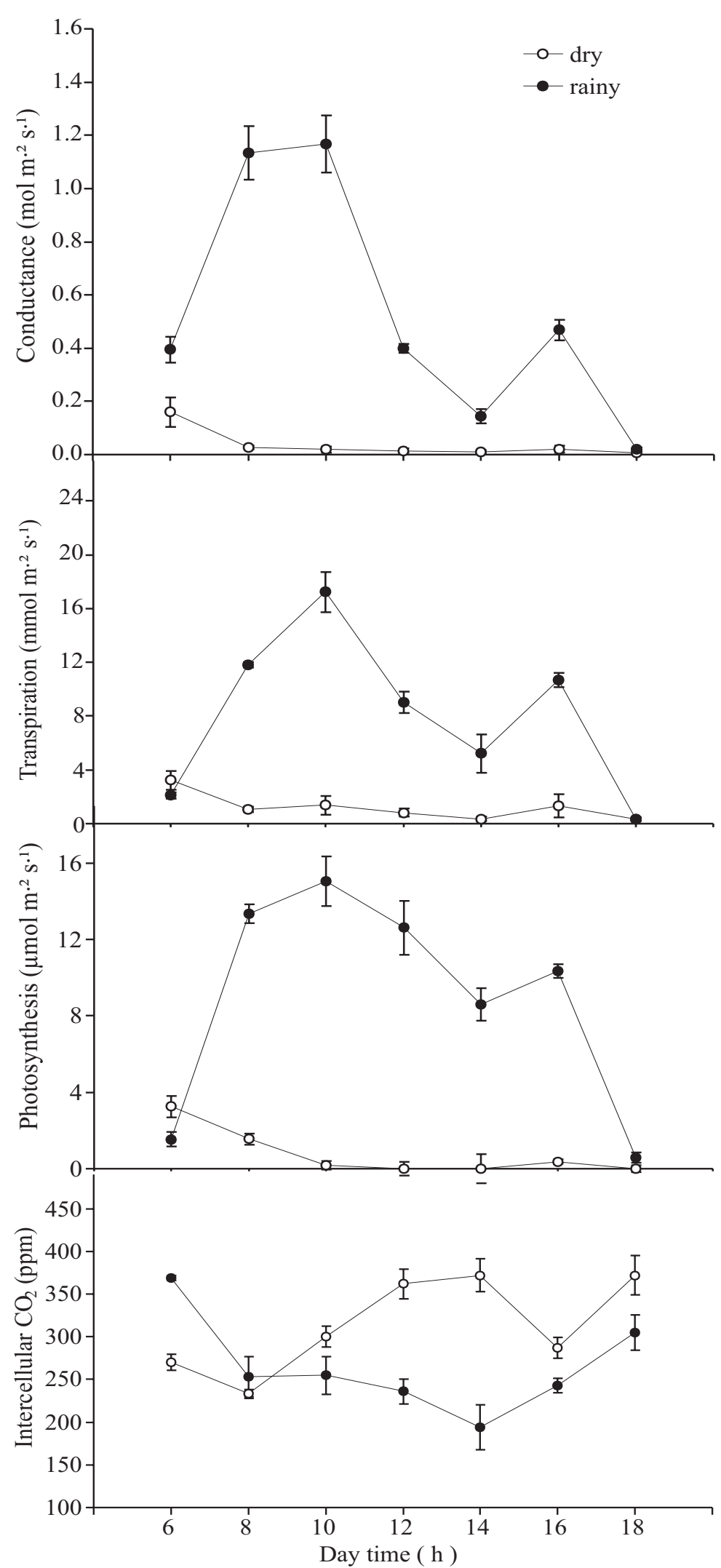

FIGURE 2 - Diurnal courses of stomatal conductance, transpiration, photosynthesis and intercellular $\mathrm{CO}_{2}$ concentration of the umbu tree, observed in the end of the dry season of 1994 and in the rainy season of 1995. Bars represent the standard deviation.

conductance reached its lowest value, around $0.01 \mathrm{~mol} \mathrm{~m}^{-2} \mathrm{~s}^{-1}$. A slight recovery to $0.02 \mathrm{~mol} \mathrm{~m}^{-2} \mathrm{~s}^{-1}$ was observed at 4:00 pm as a function of the decreasing evapotranspiratory demand. Stomatal responses to humidity may reflect a mechanism, which prevents extreme rates of water loss and extreme water deficit when plants are subjected to high evaporative demands (Schulze \& Hall, 1982).

Because stomatal conductance affects leaf gas exchange, transpiration and photosynthesis, data followed the same hourly trend. 
Therefore, leaf transpiration reached $3.22 \mathrm{mmol} \mathrm{m}^{-2} \mathrm{~s}^{-1}$ at 6:00 am, when stomatal conductance was maximum and decreased to $0.35 \mathrm{mmol} \mathrm{m}^{-2} \mathrm{~s}^{-1}$ at 2:00 pm (Figure 2). Recovery was also observed at 4:00 pm, when values were around $1.32 \mathrm{mmol} \mathrm{m} \mathrm{m}^{-2} \mathrm{~s}^{-1}$. By the end of the light period, transpiration was about zero. This pattern was also observed by Lima Filho \& Silva (1988)

Although very low, transpiration was sustained in the dry season emphasizing the importance of root tubers as water reservoir (Lima Filho, 2001). Under this condition, leaf photosynthesis seemed to be more negatively affected than transpiration. In fact, $\mathrm{CO}_{2}$ assimilation dropped from $3.25 \mu \mathrm{mol} \mathrm{m}^{-2} \mathrm{~s}^{-1}$, at 6:00 am, to around $0 \mu \mathrm{mol} \mathrm{m}^{-2} \mathrm{~s}^{-1}$, from 10:00 am to 2:00 pm. Apparent recovery happened around 4:00 pm when photosynthesis reached $0.38 \mu \mathrm{mol} \mathrm{m} \mathrm{m}^{-2} \mathrm{~s}^{-1}$, but it decreased to zero, as expected, in the end of the day. Because the umbu tree presents a $\mathrm{C} 3$ carbon fixation mechanism, it is possible that the high temperature, in addition to severe plant water stress, may have trigged the photorespiratory process and thus, playing a role on reducing assimilation (Taiz \& Zeiger, 1991). This situation may have happened because the intercellular $\mathrm{CO}_{2}$ concentration increased from around 250 $\mathrm{ppm}$, early in the morning, to $370 \mathrm{ppm}$ at 2:00 pm while assimilation decreased to near $0 \mu \mathrm{mol} \mathrm{m}^{-2} \mathrm{~s}^{-1}$ (Figure 2). In this case, part of the $\mathrm{CO}_{2}$ evolved from respiration remained intercellular due to stomatal closure.

In the rainy season the values of stomatal conductance was about $0.72 \mathrm{~mol} \mathrm{~m}^{-2} \mathrm{~s}^{-1}$ and increased to $1.17 \mathrm{~mol} \mathrm{~m}^{-2} \mathrm{~s}^{-1}$ at 10:00 am when temperature and vapor pressure deficit were $26.5^{\circ} \mathrm{C}$ and $0.96 \mathrm{kPa}$, respectively (Figure 2). From that point it dropped steadily to $0.14 \mathrm{~mol} \mathrm{~m}$ ${ }^{2} \mathrm{~s}^{-1}$ under $32{ }^{\circ} \mathrm{C}$ and $1.92 \mathrm{kPa}$ around $2: 00 \mathrm{pm}$. Recovery was observed at 4:00 $\mathrm{pm}$ when $0.47 \mathrm{~mol} \mathrm{~m}^{-2} \mathrm{~s}^{-1}$ was recorded.

Transpiration increased from $2.1 \mathrm{mmol} \mathrm{m}^{-2} \mathrm{~s}^{-1}$ by the beginning of the light period, to $17.2 \mathrm{mmol} \mathrm{m}^{-2} \mathrm{~s}^{-1}$ around 10:00 am but it decreased to $5.3 \mathrm{mmol} \mathrm{m}^{-2} \mathrm{~s}^{-1}$ at 2:00 $\mathrm{pm}$. It recovered at 4:00 pm to values around $10.7 \mathrm{mmol} \mathrm{m}^{-2} \mathrm{~s}^{-1}$ but decreased again, as expected, at 6:00 pm. In the same way, photosynthesis peaked from $1.6 \mu \mathrm{mol} \mathrm{m}^{-2} \mathrm{~s}^{-1}$ immediately after 6:00 am, to about $15.0 \mu \mathrm{mol} \mathrm{m}^{-2} \mathrm{~s}^{-1}$ at 10:00 am. Furthermore, it dropped almost linearly to $8.6 \mu \mathrm{mol} \mathrm{m}^{-2} \mathrm{~s}^{-1}$ around 2:00 pm. At 4:00 pm it increased to $10.4 \mu \mathrm{mol} \mathrm{m}^{-2} \mathrm{~s}^{-1}$, falling again to $0.6 \mu \mathrm{mol} \mathrm{m} \mathrm{m}^{-2} \mathrm{~s}^{-1}$ by $6: 00 \mathrm{pm}$.

The better performance of the umbu tree regarding assimilation during the wet season can be viewed by the course of the intercellular $\mathrm{CO}_{2}$ concentration (Figure 2), which is typically $220 \mathrm{ppm}$ in $\mathrm{C}_{3}$ species (Wong et al. 1979). In the present study, the values observed were close to this number during most part of the day.

The results indicate that during the rainy season the umbu tree showed a two-peaked daily course of stomatal conductance and consequently of water vapor and $\mathrm{CO}_{2}$ exchange. This pattern may have been caused by changes in the atmospheric environment during the day (Schulze et al., 1975), such as low air humidity, even when plants were adequately irrigated (Tenhunen et al., 1981).

\section{CONCLUSION}

1. The environmental difference between the dry and the rainy seasons is the main factor influencing the course of gas exchange of the umbu tree under semi-arid conditions.

2. In the dry season the umbu tree maintains a very low transpiration and photosynthesis during the whole day due to low levels of stomatal conductance.

3. During the rainy season, transpiration and photosynthesis of the umbu tree are high during most part of the day but the values decrease in the early afternoon as consequence of a transient decrease on stomatal conductance.

4. The umbu tree exhibits a two-picked daily course on gas exchange.

\section{ACKNOWLEDGEMENTS}

We are thankful to Dr. Eduardo Caruso Machado for his comments on the manuscript, and to Mr. Genival Nunes Ferreira for his valuable help, during data collection.

\section{REFERENCES}

BRAGA, R. Plantas do Nordeste, especialmente do Ceará. Natal: Ed. Universitária UFRN, 1976. 540p.

CAVALCANTE, N de B.; LIMA, J.L.S. de; RESENDE, G.M.; BRITO, L.T. de L.; LIMA, J.B. Extrativismo do imbuzeiro (Spondias tuberosa, Arr. Cam.) como fonte alternativa de renda para pequeno produtores no semi-árido nordestino: um estudo de caso. Ciência e Agrotecnologia, Lavras, v.20, n.4, p.529-533, 1996.

FERRI, M.G.; LABOURIAU, L.G. Water balance of plants from "caatinga" I. Transpiration of some of the most frequent species of the "caatinga"of Paulo Afonso (Bahia) in the rainy season. Revista Brasileira de Biologia, Rio de Janeiro, v.3, n.12, p.301-312, 1952.

FERRI, M.G. Water balance of plants from Caatinga II. Further information on transpiration and stomata behavior. Revista Brasileira de Biologia, Rio de Janeiro, v.3, n.13, p.237-244, 1953.

LIMA FILHO, J.M.P. Internal water relations of the umbu tree under semi-arid conditions. Revista Brasileira de Fruticultura, Jaboticabal, v.23, n.3, p.518-521, 2001

LIMA FILHO, J.M.P.; SILVA, C.M.M. de S. Aspectos fisiológicos do umbuzeiro. Pesquisa Agropecuária Brasileira, Brasília, v.10, n.23, p.1091-1094, 1988.

LIMA, R.S. de. Estudo morfo-anatômico do sistema radicular de cinco espécies arbóreas de uma área de caatinga do Município de Alagoinha-PE. 1994. 103f. Tese (Mestrado), Universidade Federal Rural de Pernambuco, Recife, 1994.

MENDES, B.V. Umbuzeiro (Spondias tuberosa Arr. Cam.) importante fruteira do semi- árido. Mossoró: ESAM, 1990. 66p.

NARAIN, N; BORA, P.S; HOLSCHUH, H.J; VASCONCELOS, M.A.A. da $S$. Variation in physical and chemical composition during maturation of Spondias tuberosa fruits. Food Chemistry, Barking, v. 44, p. 255-259, 1992.

NASCIMENTO, C.E. de S.; OLIVEIRA, V.R. de; NUNES, R.F. de; ALBUQUERQUE, T.C.S. de. Propagação vegetativa do umbuzeiro. In: CONGRESSOFLORESTAL PANAMERICANO, 1, CONGRESSO FLORESTAL BRASILEIRO, 7, 1993, Anais... Curitiba: SBS/SBEF, 1993. v.2, p.454-456.

OLIVEIRA, C.S.; SATO, A.; ESQUIBEL, M.A.; QUEIROZ, M.A.; OLIVEIRA, V.R. Propagação de Spondias tuberosa Arr. (umbú) através de cultura de tecidos. Horticultura Brasileira, Brasília, v.1, n.7, p.69-72, 1989.

SANTOS, C.A.F. Dispersão da variabilidade fenotípica do umbuzeiro no semi-árido brasileiro. Pesquisa Agropecuária Brasileira, Brasília, v.32, n.9, p.923-930, 1997.

SCHULZE, E.D.; HALL, A. E. Stomatal Responses, water loss and $\mathrm{CO}_{2}$ assimilation rates of plants in contrasting environments. In: LANGE, C.R.; NOBEL, P.S.; OSMOND, C.B; ZEIGLER, H. (Ed.) Physiological plant ecology II: Water relations and carbon assimilation. Berlin: Springer-Verlag, 1982. Cap. 7, p.182-230.(Encyclopedia of Plant Physiology, New Series, 12 B).

SCHULZE, E.D.; LANGE, O.L; KAPPEN, L.; EVENARI, M.; BUSHBON, $\mathrm{U}$. The role of air humidity and leaf temperature in controlling stomatal resistance of Prunus armeniaca L. under desert conditions. II. The significance of leaf water status and internal carbon dioxide concentration. Oecologia, Heldelberg, v.18, p.219233, 1975.

TAIZ, L; ZEIGER, E. Plant Physiology. California: The BenjaminCummings Publishing Company, 1991. 559p.

TENHUNEN, J.D.; LANGE, O.L; BRAUN, M.; MEYER, A. ; LÖSCH, R.; PEREIRA, J.S. Midday stomatal closure in Arbutus unedo leaves in a natural macchia and simulated habitat conditions in an environmental chamber. Oecologia, Heldelberg, v. 47, p.365-367, 1981.

WONG, S.C.; COWAN, I.R.; FARQUHAR, G.D. Stomatal conductance correlates with photosynthetic capacity. Nature, London, v.282, p.424-426, 1979 . 